\title{
Review \\ Internet of Things (IoT) Technology Research in Business and Management Literature: Results from a Co-Citation Analysis
}

\author{
Andreas Korte ${ }^{1}$, Victor Tiberius ${ }^{1, *(D)}$ and Alexander Brem ${ }^{2,3}$ \\ 1 Faculty of Economics and Social Sciences, University of Potsdam, 14469 Potsdam, Germany; \\ andreas.korte@uni-potsdam.de \\ 2 Institute of Entrepreneurship and Innovation Science, University of Stuttgart, 70569 Stuttgart, Germany; \\ alexander.brem@eni.uni-stuttgart.de \\ 3 Department of Technology and Innovation, University of Southern Denmark, 6400 Sønderborg, Denmark \\ * Correspondence: tiberius@uni-potsdam.de
}

Citation: Korte, A.; Tiberius, V.; Brem, A. Internet of Things (IoT) Technology Research in Business and Management Literature: Results from a Co-Citation Analysis. J. Theor. Appl. Electron. Commer. Res. 2021, 16, 2073-2090. https://doi.org/10.3390/ jtaer16060116

Academic Editor: Carman K. M. Lee

Received: 25 June 2021

Accepted: 12 August 2021

Published: 17 August 2021

Publisher's Note: MDPI stays neutral with regard to jurisdictional claims in published maps and institutional affiliations.

Copyright: (c) 2021 by the authors. Licensee MDPI, Basel, Switzerland. This article is an open access article distributed under the terms and conditions of the Creative Commons Attribution (CC BY) license (https:// creativecommons.org/licenses/by/ $4.0 /)$

\begin{abstract}
In coherence with the progressive digitalization of all areas of life, the Internet of Things (IoT) is a flourishing concept in both research and practice. Due to the increasing scholarly attention, the literature landscape has become scattered and fragmented. With a focus on the commercial application of the IoT and corresponding research, we employ a co-citation analysis and literature review to structure the field. We find and describe 19 research themes. To consolidate the extant research, we propose a research framework, which is based on a theoretical implementation process of IoT as a concept, specific IoT applications, or architectures integrated in an adapted input-processoutput model. The main variables of the model are an initial definition and conceptualization of an IoT concept (input), which goes through an evaluation process (process), before it is implemented and can have an impact in practice (output). The paper contributes to interdisciplinary research relating to a business and management perspective on IoT by providing a holistic overview of predominant research themes and an integrative research framework.
\end{abstract}

Keywords: bibliometric analysis; business; co-citation analysis; Internet of Things; IoT; management

\section{Introduction}

The Internet of Things (IoT) envisions a global ecosystem connecting diverse objects to the internet [1,2]. By using embedded technologies, especially sensors, these objects communicate with each other and generate and exchange data without human intervention, based on a connection through the internet [3,4]. The term "Internet of Things" was coined in 1999 by Ashton, co-founder of the Auto-ID Center at Massachusetts Institute of Technology (MIT), when presenting the idea of using radio-frequency identification (RFID) tags in supply chains to link physical objects with the internet [5-7]. The concept of a connected devices network, however, has already been discussed before. Weiser addressed a network of connected devices almost a decade earlier [8]. Reports on the development of devices, which could be called IoT devices today, even go back to the early 1980s. For instance, in 1982, a modified Coca-Cola vending machine at the Carnegie Mellon University in Pittsburgh was able to report its stock and the temperature of new loaded drinks via the internet [9]. In contrast, Jesus et al., consider an internet-connected toaster introduced by John Romkey in 1990 as the first IoT device that could be switched on and off [10]. Today, Tesla is considered a pioneer for helping shape the general idea of the IoT [11].

The IoT is projected to have enormous potential to influence and change the society, economy, and environment [2,12]. In this paper, we focus on the economic dimension, and more specifically, the business and management perspective on IoT, as the IoT can be seen as a radical innovation [13], which has the potential to innovate many existing business models and generate completely new ones [14-19]. Ashton and Chambers believe that the IoT has a revolutionary potential, even more than the internet itself has [20]. Cisco expect 
in their Annual Internet Report to see more devices connected to the internet than having humans worldwide by 2023, even by a factor of three [21]. The McKinsey Global Institute estimates the financial impact of IoT on the general economy to be USD 11.1 trillion by 2025 [22]. The currently most affected sectors of IoT applications are smart cities [23], smart homes, healthcare, supply chains, logistics and transportation [24], security, and others [6,25]. Therefore, "the IoT can be perceived as a vision with technological and societal implications" [26] (p. 1).

The impact and relevance of the IoT is also reflected in its evolution as a research field. As illustrated in Figure 1, a rapid increase in scholarly publications addressing IoT has been recorded over the last decade. The figure shows the years on the $x$-axis and the number of publications as columns on the $y$-axis, with the publication numbers on the right side. Whereas in the year 2010, only 17 publications with the term "Internet of Things" in their title had been indexed in the Web of Science (WoS); by 2020, this figure had risen to 1706 publications, which corresponds to an increase of approximately 530 percent and reflects the growing interest in this research field. The development of citations received by these publications show a similar pattern, as also depicted in Figure 1, by the curve and the citation numbers on the left side. This rapid growth resulted in a fragmented and complex research landscape, which will serve as a basis for academic and industrial researchers for a long time [27]. However, the massive growth of publications is also problematic, as the field is hard to oversee, and academic progress depends on a common and clear understanding of the relevant concepts for further exchange and knowledge building [28].

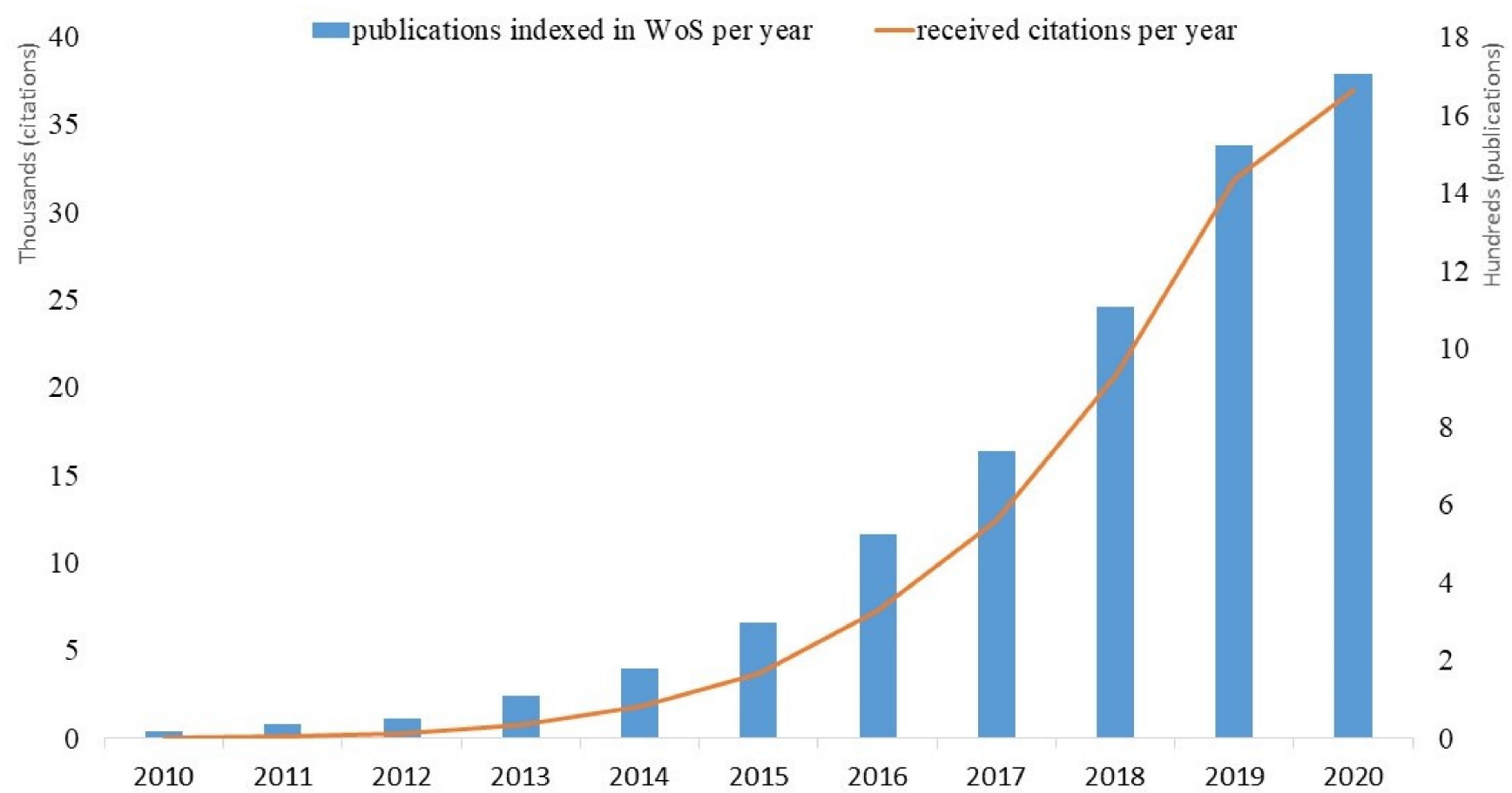

Figure 1. Evolution of IoT research field (left: citations, right: publications). Source: Own elaboration based on WoS.

To help business and management scholars gain general insights into economic aspects of the IoT and identify future research opportunities within the field, its systematic structuring is essential. To do so, we employ a bibliometric analysis, or more specifically, a co-citation analysis of business- and management-related IoT research.

Our study exceeds and supplements previous bibliometric analyses on the IoT regarding the thematic focus and methodology. For example, Rejeb et al. conducted a keyword co-occurrence analysis regarding IoT in supply chain management and logistics [29]. Similarly, Ben-Daya et al., in their literature review and bibliometric analysis, focused on supply chains [30]. The work by Dantu et al. aimed to identify key topics in the scholarly literature 
on IoT in healthcare through data clustering based on a combination of text and bibliometric analysis [31]. Further bibliometric studies focus on IoT applications in food safety [32] or marketing [33]. While these studies focus on specific sectors or fields, others center around specific functional aspects. For example, Dadkhah et al. conducted a bibliometric analysis on research that deals with opportunities and limitations to the use of IoT, such as security, privacy, trust, standards, architecture, and energy [34]. Mishra et al. provided an overview of the most influential authors in research on the vision and application of IoT [35]. Li et al. focus on development and innovation of IoT [36]. Other bibliometric studies or literature reviews of IoT also show temporal and thematic limitations [37-39]. In contrast to these studies, our bibliometric analysis covers all research that relates to the IoT in business and management research. Apart from this broader thematic focus, our insights from a science mapping based on article titles, abstracts, and keywords is more thorough than, for example, a keyword clustering alone [29].

With this study, we contribute to research at the interdisciplinary intersection of digitalization and business and management studies by providing a systematic overview of predominant research themes, which are integrated into a research framework that structures previous research and shows gaps to be addressed by future research.

The remainder of this article is organized as follows. In Section 2, the theoretical background of IoT is reviewed. Section 3 outlines the employed co-citation analysis. In Section 4 , the results are presented. The findings and their implications are discussed in Section 5. We conclude with a discussion of the limitations of the study and future research opportunities in Section 6.

\section{Theoretical Background}

\subsection{Definitions}

As part of the "Future Internet" [11,40], the IoT has become a constantly evolving paradigm that is under the influence and interests of a wide range of stakeholders [41]. Despite a broadly common understanding of the IoT, a unified definition is still lacking [38], as definitions are suggested from different understandings and perspectives. As a consequence, different aspects are highlighted. Atzori et al. identify three main perspectives: (1) internet-oriented, centering on the network-based connectivity and aspects such as network protocols; (2) thing-oriented, focusing on the identity and functionality of the things that are connected; (3) semantic-oriented, addressing the challenges of handling IoT data [42]. Depending on the perspective, different characteristics are stressed. Connectivity, heterogeneity, scalability, interoperability, and security/safety can be considered as the most fundamental IoT characteristics $[25,43]$. Another approach to grasp the main IoT characteristics is by looking at its architecture. A general IoT architectural framework does not exist $[2,44]$. Rather, most proposed architectures relate to specific application types $[45,46]$. However, according to Tsai et al., an IoT architecture basically consists of three layers: (1) a sensing or physical layer that performs the data sensing and collection, (2) an application layer that provides services or applications for analyzing and integrating the received data, and (3) a network layer functioning as a connection to exchange data between the other two layers [47]. Similarly, the CASAGRAS (Coordination and Support Action for Global RFID-related Activities and Standardisation) project distinguishes three layers, (1) a physical layer for identifying the physical things, (2) an information management, application, and enterprise layer providing the platform for the applications and services, and (3) an interrogator-gateway layer providing the required boundaries between the two other layers [48]. More service-oriented IoT architectures add a service layer, which provides and manages the required services by both users and applications $[1,42,49]$.

The difficulty of establishing a unified definition is demonstrated by the 86-page report "Towards a Definition of the Internet of Things" by Minerva et al. [50]. They suggest to use two distinct definitions based on different scenarios. Another definition approach comes from the Telecommunication Standardization Sector of the International Telecommunication Union (ITU-T), and states that the Internet of Things is "a global 
infrastructure for the information society, enabling advanced services by inter-connecting (physical and virtual) things based on, existing and evolving, interoperable information and communication technologies" [26] (p. 1).

The physical or virtual objects have to be (1) able to communicate, (2) identifiable, (3) able to interact with their environment $[25,40]$. The spectrum of these physical objects ranges from computers and smartphones to everyday household objects such as furniture or toys [7]. IoT data can also stem from individuals or animals [38]. These things have to be connected over the internet, rather than other communication networks [50].

All the partial aspects of the IoT's definition and conceptualization determine the technological progress in IoT, especially the variety and complexity of devices, their sensors, and the speed and quality of their connectivity and communication. All these partial aspects have massively improved over the past years. More and more devices get connected to the internet (see next section on application areas). Biosensors, chemical, physical, and other sensor types detect a vast variety of events and changes. Furthermore, the communication over the internet has seen exponential improvements by growing bandwidths and record speeds through wired and wireless networks.

\subsection{Application Areas}

The IoT technology can, in general, be applied to all areas human beings deal with. In the literature, different classifications of application areas can be found. Guillemin and Friess distinguish the society, industry, and environment as three broad and overlapping application domains, with several sub-domains [51] (Figure 2). Another classification is suggested by Gubbi et al. who identify four application domains for the IoT: (1) in the personal and home domain, where the IoT can help improve daily living issues, such as home and energy management; (2) the enterprise domain, with an impact on a community level, such as public health or public transportation and infrastructure issues; (3) the utility domain, which represents the surveillance sector; and (4) the mobile domain relating to wireless applications used out and about [52]. Miorandi et al. provide a comprehensive list of IoT application fields including environmental monitoring, smart cities, smart businesses as well as inventories and product management, smart homes and smart building management, healthcare, and security and surveillance [25]. $\mathrm{Ng}$ et al. exemplarily mention IoT application fields such as agriculture and livestock or product lifecycle management [6]. Many other fields, such as the electricity $[53,54]$ or retailing sector [55], can be added.

According to the respective application area, different IoTs can be distinguished. The so-called Internet of Healthcare Things or Internet of Medical Things relates to healthcare issues and is among the areas most rapidly using IoT technologies [56-62]. Using more medical devices leads to higher volumes of medical data. Moreover, shorter innovation cycles in medical technologies push the need the need for a digitized and interconnected healthcare system. With IoT technology, the efficiency of medical devices and the health system as a whole can be improved [63]. Recently, the IoT technologies are being used to fight the COVID-19 pandemic [64-68]. The Industrial Internet of Things (IIoT) focuses on manufacturing and production $[69,70]$ and aims to bring improvements in operational efficiency, production processes, and the development of new business models [71]. Srinivasan et al. explore further IoT extensions, such as the Internet of Everything, or the Internet of Mobile Things, to name a few [72]. 


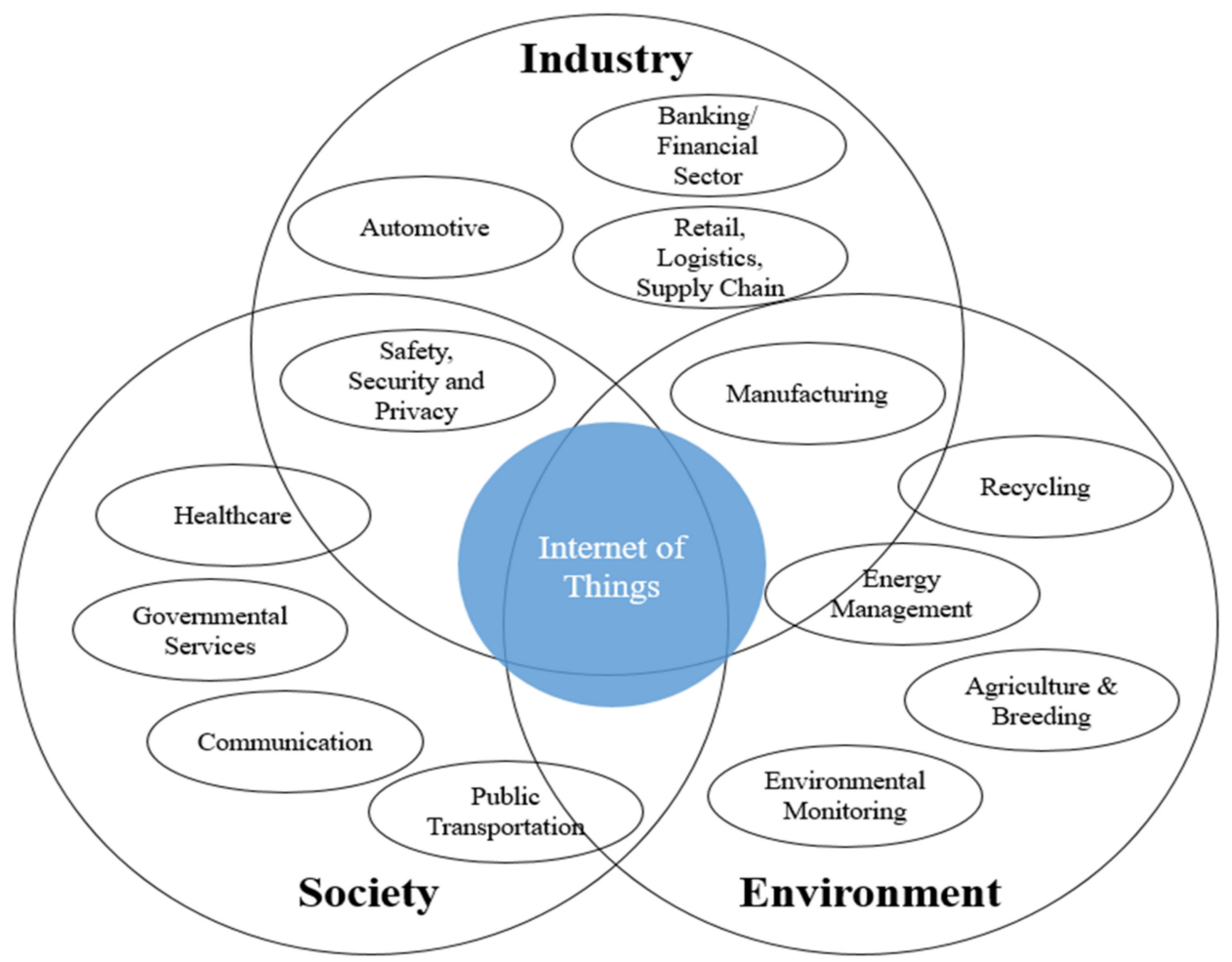

Figure 2. Application domains. Source: Based on Guillemin and Friess (2009) [51].

\section{Methodology}

\subsection{Co-Citation Analysis}

For this article, a bibliometric analysis, more specifically, a co-citation analysis, was employed. Pritchard used the term bibliometrics to replace the concept of statistical bibliography [73]. Accordingly, bibliometrics deal with "the application of mathematical and statistical methods to books and other media of communication" [73] (p. 349). Today, bibliometrics is a widely used instrument to measure the state of science [74]. As a specific bibliometric analysis, science mapping techniques structure the body of literature in a field based on quantitative measures that describe the connections between publications [74-85].

Two documents are referred to as "co-cited" if they have a joint appearance on the reference list of a citing document $[31,86,87]$. The key notion is that the greater the cocitation strength of two documents, the more likely they share the common research theme $[87,88]$. Co-citation analysis is considered to be robust for identifying and filtering the most important papers [74].

\subsection{Data Collection and Data Analysis}

For the co-citation analysis, data from the Web of Science (WoS) database were extracted. WoS is considered a leading scientific online citation and literature database and is widely used in bibliometric analyses [6,89].

To ensure that the publications used for the analysis focus on the topic of Internet of Things, rather than deal with it in passing, a title rather than topic search with the keywords 'Internet of Things' and 'IoT' was conducted. The related areas were limited to the WoS categories 'business' and 'management' and document types 'article', 'early access', and 'review'. The search process conducted on 6 January 2021 yielded 260 documents with a total of 12,755 references.

VOSviewer version 1.6.16 was used to cluster the data and generate a bibliographic map $[9,90]$. To focus only on the most relevant publications and to work with a manageable data set, a citations threshold was set to a minimum of five [74]. As a consequence, the data set was slightly reduced to 194 documents. In the next step, based on the literature 
review, the semantic relationships of the documents within the respective clusters and to sub-clusters were carried out and analyzed.

\section{Results}

Figure 3 shows the 194 publications and 6583 links, separated into five research clusters identified by the co-citation analysis. Publications are represented as dots, whereas the links or connections between publications are depicted by lines. Publications with a higher weight are displayed more prominently than those with lower weighting. The different colors indicate the clusters to which the items were assigned by the clustering technique of the software [90]. The 'total link strength' of 11,526 reflects the overall strength of the interconnections between the publications.

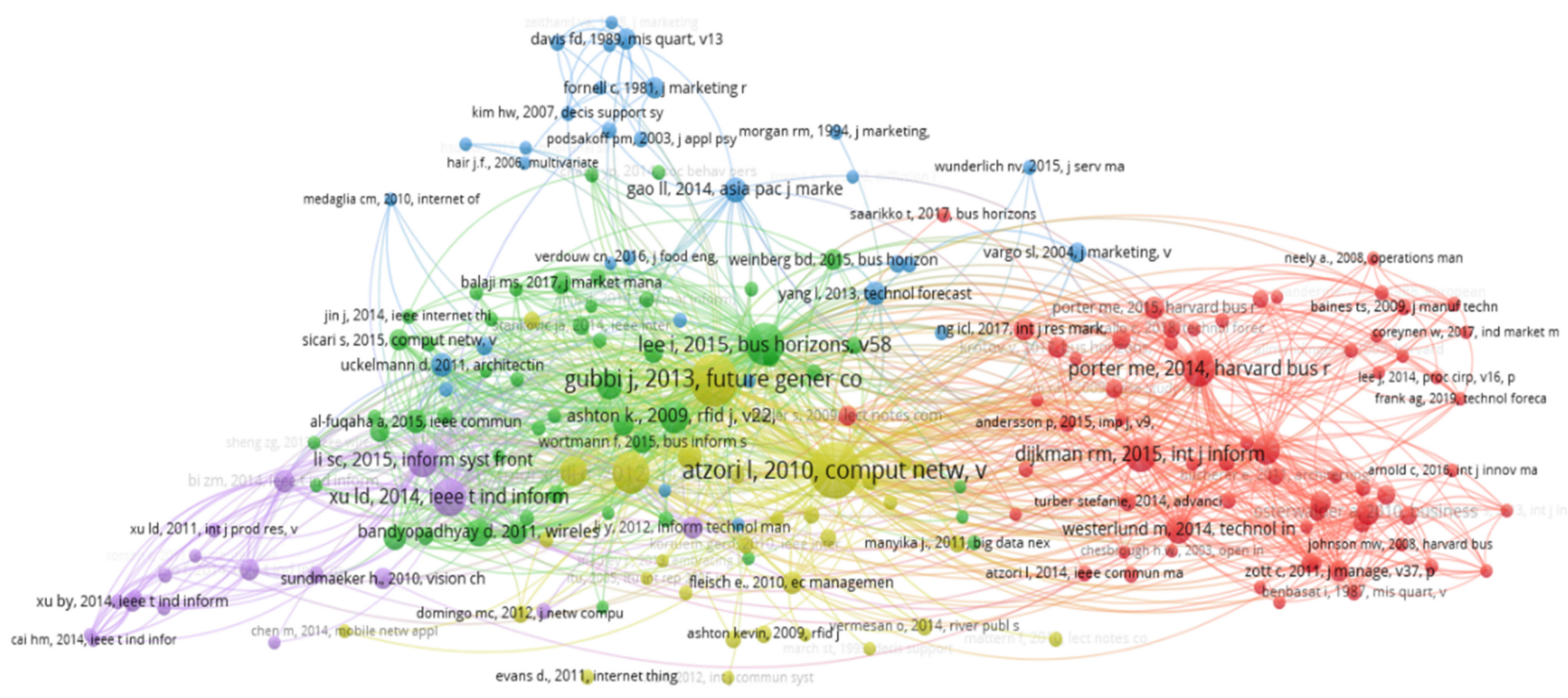

Figure 3. Bibliographic map. Source: Own elaboration based on VOSviewer.

The literature review showed that various topics are addressed within each of the five clusters. Therefore, a further subdivision into sub-clusters was created. Furthermore, it revealed that some topics are addressed on a cross-cluster basis. The research clusters and their sub-clusters are presented in Table 1 and can be described as follows.

\subsection{Cluster 1 (Red)}

With 65 publications, this is the largest of the five research clusters and can be divided into the following three sub-clusters:

Sub-Cluster 1.1-IoT and Business Models (in General): This large sub-cluster consists of 43 publications which mainly deal with the design of business models in the emerging context of the IoT. A business model is "the plan implemented by a company to generate revenue and make a profit from operations" and is thus inextricably linked to the success of the company [91]. Due to rapid technological progress and the constantly changing conditions in which products are designed, manufactured, or distributed on the one hand, and the growing market competition on the other, companies are facing the strategic decision to review their existing business models and adapt them to the new circumstances [92]. Some publications in this cluster address this issue by discussing the development of innovative digital business models, without making direct reference to the IoT [93-95]. Most of the publications, including the most cited ones, deal with business models in the context of the IoT or with business models specifically designed for the IoT. Westerlund et al., for example, identified in their research, focused on the challenges of designing business models for the IoT, the diversity of objects, and the immaturity of innovation and unstructured ecosystems as the three key issues hindering businesses from establishing business models and monetizing the IoT [7]. Dijkman et al. present in their paper a framework for a business 
model designed especially for applications of the IoT regarding the value proposition as its most important element [96].

Table 1. Cluster overview.

\begin{tabular}{|c|c|c|c|}
\hline Cluster & Sub-Cluster & Description & $\begin{array}{l}\text { Number of } \\
\text { Publications }\end{array}$ \\
\hline \multirow{3}{*}{1} & 1.1 & IoT and Business Models (in General) & 43 \\
\hline & 1.2 & Servitization-Service-Oriented Business Models & 13 \\
\hline & 1.3 & Analysis, Research, and Theory Building Methods I & 9 \\
\hline \multirow{6}{*}{2} & 2.1 & IoT Applications: Standards, Challenges, and Impact & 14 \\
\hline & 2.2 & IoT Security, Privacy, Legal, and Social Issues & 17 \\
\hline & 2.3 & IoT-Enabled Supply Chains & 8 \\
\hline & 2.4 & Research Reviews and Outlooks I & 6 \\
\hline & 2.5 & IoT-Enabled Smart Cities & 3 \\
\hline & 2.6 & Analysis, Research, and Theory Building Methods II & 1 \\
\hline \multirow{5}{*}{3} & 3.1 & Acceptance of IoT & 9 \\
\hline & 3.2 & Strategic Management Models (in Marketing) & 7 \\
\hline & 3.3 & Analysis, Research, and Theory Building Methods III & 5 \\
\hline & 3.4 & IoT: Methodological and Technological Propositions I & 4 \\
\hline & 3.5 & Research Reviews and Outlooks II & 5 \\
\hline \multirow{3}{*}{4} & 4.1 & Impact of Big Data & 4 \\
\hline & 4.2 & IoT: Methodological and Technological Propositions II & 4 \\
\hline & 4.3 & Research Reviews and Outlooks III & 23 \\
\hline \multirow{2}{*}{5} & 5.1 & IoT: Methodological and Technological Propositions III & 11 \\
\hline & 5.2 & Research Reviews and Outlooks IV & 7 \\
\hline
\end{tabular}

Sub-Cluster 1.2-Servitization-Service-Oriented Business Models: The second subcluster within the first research cluster contains 13 publications. While the publications of the first sub-cluster deal with business models and IoT in a more general context, this sub-cluster focuses specifically on the process from product-centric to service-oriented business models with the use of IoT. A development that affects manufacturing companies in particular and is called servitization [97]. The most cited paper within this sub-cluster by Rymaszewska et al. presents a framework for companies to extend their value chains and as a result increase their profitability based on an IoT aided servitization [98].

Sub-Cluster 1.3-Analysis, Research, and Theory Building Methods I: The smallest of the three sub-clusters, comprising nine publications, is completely detached from the topic of IoT and deals with analysis, research, and theory building methods in general. One of the main topics in this context is the case study as a research method [99-102]. This sub-cluster occurs within further of the five research clusters and given their topics one can assume that these publications were cited for definition purposes of different methodologies and theories.

\subsection{Cluster 2 (Green)}

The second was the most indistinguishable of the research clusters and covered a wide range of topics, thus the following six sub-clusters were formed:

Sub-Cluster 2.1-IoT Applications: Standards, Challenges, and Impact: The 14 articles in this sub-cluster deal with potential IoT applications and those already in use and how these influence different areas in the private and economic sectors, as well as the challenges 
they face. In addition to a review of what they consider to be the most important IoT technologies for the implementation of successful products and services, Lee and Lee identify three IoT application categories which help companies increase customer value [103]. Accordingly, IoT applications can be divided into the following categories: monitoring/control, big data/business analytics, and information sharing/collaboration [103]. Kim and Kim, on the other hand, assess the applicability and emerging challenges of IoT applications in Korea in the three areas of healthcare, logistics, and energy management through a model and expert interview [104].

Sub-Cluster 2.2-IoT's Security, Privacy, Legal, and Social Issues: The second subcluster includes 17 publications concerned with security and privacy as well as social and legal/policy issues regarding the IoT. In the era of IoT and immense data generation and exchange, Weber proposes a global, heterogeneous, and differentiated legal framework, without geographical limitations, to meet the security and privacy demands of the stakeholders involved, such as data protection or client architecture's resilience to attacks [105]. Similarly, Sicari et al. address the issue of security and privacy within the IoT context but place the focus on the needed infrastructure characteristics, e.g., flexibility and scalability to deal with these issues [106]. In addition to safety and secrecy issues as well as legal requirements, social issues that arise in connection with IoT are also discussed in this sub-cluster $[107,108]$. For example, Yan et al. see in the adaptation of trust management techniques and technologies a suitable tool for overcoming concerns about IoT services and applications and thus increasing their acceptance [109].

Sub-Cluster 2.3-IoT-Enabled Supply Chain (Management): This sub-cluster consists of eight publications, addressing the possibilities, challenges, and opportunities of the integration of IoT into supply chains and the impact on supply chain management (SCM). The most cited publication in this sub-cluster is a literature review carried out by Ben-Daya et al. [30]. Their focus was on the current state of research regarding IoT's impact on SCM. The focus of further publications in this sub-cluster is particularly on the operationalization of IoT-generated consumption data for supply chains and their impact on SCM [110,111].

Sub-Cluster 2.4-Research Reviews and Outlooks I: The topic addressed in this subcluster, namely the review of the current state of academic research and an insight into possible research outlooks on the subject of IoT, is also covered in further sub-clusters of further research clusters. This sub-cluster contains six publications. Khan et al., for example, propose a generic structure for the IoT and describe possible future applications and challenges, as well as presenting examples of some international research projects in the field of IoT [112]. Mishra et al. work in this field of IoT by reviewing the most influential authors and works, and emphasizing existing and emerging research clusters based on a bibliometric analysis [35].

Sub-Cluster 2.5-IoT-Enabled Smart Cities: With three publications, the fifth subcluster is one of the smallest within this second research cluster and addresses how the IoT can be used in or influences the development of smart cities. An example of what this might look like is described by Zanella et al. in their work on urban IoT systems, specifically designed IoT systems to support the implementation of smart cities [113]. The authors provide an overview of key technologies and architectures and present the Padova Smart City project, an IoT Island in Padova, Italy; a feasible example for an urban IoT system [113].

Sub-Cluster 2.6-Analysis, Research, and Theory Building Methods II: Given that only a single publication is involved here, it is not really a sub-cluster. However, this publication does not fit thematically into any of the previously listed sub-clusters in this research cluster and is therefore treated separately. The paper by Webster and Watson touches only marginally on the research area of information systems and functions more as a guideline for writing a literature review in general [114]. It would fit thematically more into sub-cluster 1.3. 


\subsection{Cluster 3 (Blue)}

The third research cluster, with 31 publications, is only half the size of the first, but is similarly fuzzy as the second and therefore had to be subdivided into the following five sub-clusters:

Sub-Cluster 3.1-Acceptance of IoT: The largest of the five sub-clusters consists of nine publications dealing with the acceptance and adoption of information technology and IoT. Almost all authors of this sub-cluster use the Technology Acceptance Model (TAM). The TAM method was developed by Davis in 1989 to measure or evaluate user acceptance of IT, as the theoretical base of their studies [115]. Some of the publications only aim to theoretically further develop the TAM without really referring to IoT $[116,117]$. Gao and Bai propose a model of IoT acceptance consisting of three technological components, one social context aspect and two individual user attributes [115]. To test their model, the authors used a structural equation model (SEM), an approach also used in the work by Mital et al. [118] to test different acceptance models in the context of IoT adaptation in India.

Sub-Cluster 3.2-Strategic Management Models (in Marketing): The second subcluster comprises seven publications dealing with the development of strategic management models (without reference to IoT). The two most cited publications discuss the development and characteristics of the service-dominant logic of marketing, an approach in contrast to the goods-centered paradigm to explain value creation $[119,120]$. The other publications are older works from the 1990s that deal with theoretical approaches regarding wealth creation or competitive advantage [121,122].

Sub-Cluster 3.3-Analysis, Research, and Theory Building Methods III: Similar to subclusters 1.3 and 2.6, the six publications in this sub-cluster explore different analytical and theoretical models, e.g., multivariate data analysis, the structural equation model, diffusion of innovations theory, or the issue of common method bias as well as the absorptive capacity of companies [123-128]. The publications do not have any direct reference to the topic of IoT.

Sub-Cluster 3.4-IoT: Methodological and Technological Propositions I: In this subcluster, four publications are grouped together, which deal with methodological or technological IoT-related concepts designed to improve a wide range of areas, a thematic field which is found in more than one of the five research clusters. Scuotto et al. investigate the potential benefits of a combination between the IoT and the Open Innovation (OI) model [129], whereas Yang et al. describe in their work how the use of IoT technologies can make emergency response operations more efficient and less resource-intensive [130].

Sub-Cluster 3.5-Research Reviews and Outlooks II: While the publications of the previous sub-cluster address very concrete concepts of the IoT in specific application fields, the authors of the five publications in this sub-cluster, like sub-cluster 2.4, aim to provide a holistic overview of the topic of IoT and thus provide guidance for future research. One of these publications, for example, is the cluster book published in 2010 by Sundmaeker et al. on the behalf of the CERP-IoT (The European Research Cluster on the Internet of Things) with the objective of addressing both the potential and the challenges of IoT in Europe [40]. With his work, Ma pursues the same goal but with a focus on China [131]. Medaglia and Serbanati focus on arising security and privacy issues within the IoT context [132].

\subsection{Cluster 4 (Yellow)}

With 31 publications, the fourth research cluster was as large as the third, but not as blurry, which is why it was appropriate to divide it into the following three sub-clusters:

Sub-Cluster 4.1-Impact of Big Data: The first of the three sub-clusters contains four publications that deal with big data, a topic that correlates with IoT. According to the McKinsey Global Institute publication by Manyika et al., data or especially big data is an important factor in production, which will increase in importance in the future as a result of the growing number of data-generating IoT applications [22]. Chen et al. also see IoT applications as an important source to collect big amounts of data [133]. Data generated 
by such applications can therefore be considered effective, heterogeneous by large scales, and with a strong time-space correlation [133]. In contrast, the other two publications in this sub-cluster discuss the topic of big data in the context of business intelligence and analytics and management decisions, respectively, without making any specific reference to the IoT [134].

Sub-Cluster 4.2-IoT: Methodological and Technological Propositions II: This subcluster, like sub-cluster 3.4, addresses IoT-related methodological or technological approaches to overcome different challenges. For example, the paper by Domingo, which is the most cited of the four publications in this sub-cluster, deals with the benefits of IoT for people with disabilities and elaborates on the relevant application scenarios [135]. Kortuem et al. focus on smart objects as an important part of the IoT and present an architectural framework for these objects to help to support complex applications by increasing their interactive capabilities [136].

Sub-Cluster 4.3-Research Reviews and Outlooks III: The largest of the three subclusters contains 23 publications. Similar to sub-clusters 3.5 and 2.4, this sub-cluster groups studies reflecting the current state of research at the time of their publication as well as an outlook for future research in the field of IoT. Atzori et al. [42] and Gubbi et al. [52] are the two most cited papers in this sub-cluster. Both papers attempt to present the current state of IoT research by reviewing the key enabling technologies and application fields, also by presenting their visions of the IoT and finally, by identifying the main research issues. Atzori et al. present in their survey three visions that arise due to different perspectives on the IoT, namely of a thing-oriented, an internet-oriented, or a semantic-oriented one [42]. Gubbi et al. focus on a cloud centric vision for the global implementation of the IoT and present a framework based on the cloud platforms Aneka and Microsoft Azure [52]. By reviewing visions, key technologies, potential application domains, and open research issues, the majority of the other articles in this sub-cluster have a similar, if not the same, thematic focus as the two previously mentioned $[2,25,137]$. A few of the publications, on the other hand, try to shed light on the IoT paradigm from an economic perspective. For example, the work by Fleisch aims to help companies use IoT to become more profitable [27]. In addition, the work of Bradley et al., a Cisco white paper, presents use cases to help companies move organizationally towards IoT and benefit from it [138].

\subsection{Cluster 5 (Purple)}

With 18 publications and the following two sub-clusters, the fifth and last one is the smallest of the research clusters:

Sub-Cluster 5.1-IoT: Methodological and Technological Propositions III: This subcluster consists of eleven publications which, like the publications in sub-clusters 3.4 and 4.2, deal with different methodological and technical approaches regarding the use and handling of the IoT. In their work, $\mathrm{Xu}$ et al. present an IoT-based method for supporting emergency medical services, based on a semantic data model and a self-developed, resource-based data access method for capturing and processing data [139]. In their work, Atzori et al. investigate the Social IoT, a paradigm based on the integration of social networking concepts in IoT solutions [140]. Among other aspects, they describe the necessary properties and a potential architecture to implement the Social IoT [140]. Tao et al. present a cloud computing and IoT-based cloud manufacturing service system to help realize the utilization, distribution, and allocation of different manufacturing resources and capabilities [141].

Sub-Cluster 5.2-Research Reviews and Outlooks IV: The last sub-cluster includes seven publications aiming to offer a holistic view of the IoT research landscape, similar to sub-clusters 2.4, 3.5, and 4.3. An example is the survey by Li et al., which provides an overview of definitions, technologies, and architecture of the IoT [49]. The survey by Xu et al. focuses on the IoT in the industry context [139]. 


\section{Discussion and Implications}

In this co-citation analysis, we structured the IoT research landscape in business and management. The analysis led to five research clusters, which were further subdivided into sub-clusters based on a literature review. The results suggest that IoT in business and management is a constantly growing and complex research field. The proposed research framework is based on a theoretical implementation process of IoT as a concept or specific IoT applications and/or architectures integrated. The framework represents a theoretical implementation process associated with IoT, based on an input-process-output (IPO) model with three main variables: definition/conceptual design (input), evaluation (process), and implementation/impact (output). Based on the analysis and oriented by the framework, an overview of the current state of research, as well as potential research gaps and future research directions, were identified.

Due to the complexity and rapid growth of scientific and economic interest in IoT, we propose a research framework (Figure 4) to organize the relevant knowledge in a coherent way, serving as a reflection of the current state and guidelines for future research.

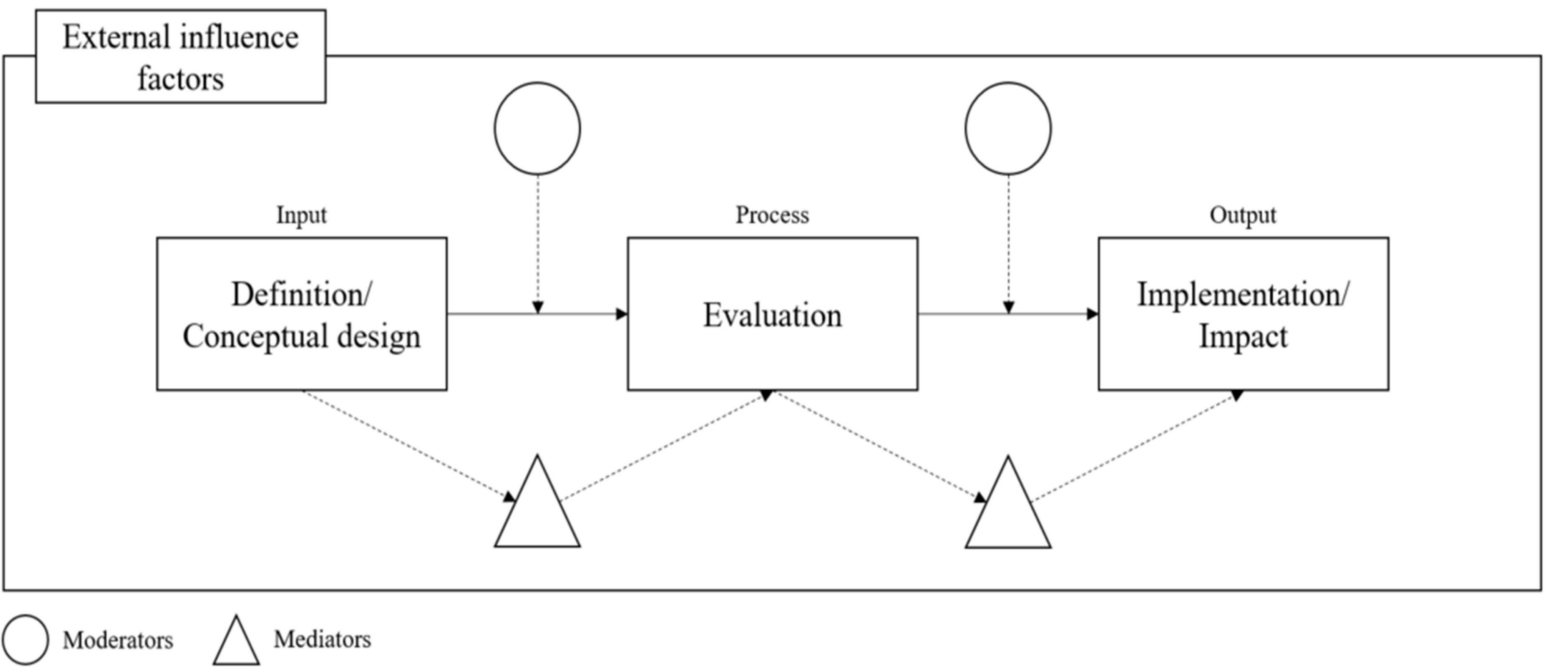

Figure 4. Proposed conceptual model framework. Source: Own elaboration.

The framework is based on a theoretical implementation process of IoT as a concept or specific IoT applications or architectures integrated in an adapted input-process-output (IPO) model. The main variables of the model are an initial definition and conceptualization of an IoT concept (input), which goes through an evaluation process (process), before it is implemented and can have an impact in practice. The model is framed by various external factors which affect these variables. In addition, both mediator and moderator effects have an impact on the implementation process.

The publications of the clusters and sub-clusters identified in the course of the analysis deal with one or more described variables of the framework, whereas some are neglected. The publications of sub-clusters 2.4, 3.5, 4.3, and 5.2 present a holistic overview of the IoT research landscape and provide guidance for future research. Therefore, they can be seen as an upstream basis for the input variable, enabling researchers to develop and propose new definitions, concepts, and applications of the IoT or to adapt and further develop existing ones.

Numerous publications throughout different sub-clusters deal with use-case specific IoT concepts, applications, architecture proposals, and the potential impact of their implementation, and thus, address both input and output variables of the framework. The rather small sub-clusters 2.5 and 2.3 focus on IoT concepts and their impact on the development of smart cities, respectively, and the optimization of supply chains; for example, how the operationalization of IoT-generated data can help improve reverse supply chains [111]. 
The sub-clusters $2.1,3.4,4.1,4.2$, and 5.1 serve as a cross-domain repository for a variety of publications proposing IoT applications, concepts, and architectures. These include, for example, the domains of healthcare in the form of emergency medical services $[130,135,139]$, manufacturing [141], or big data [133]. Given the number of publications, another one of the most researched topics, which addresses the two variables input and output of the framework simultaneously, is the presentation of IoT-based strategic management models (sub-cluster 3.2) and business models (sub-cluster 1.1). This result is also in line with earlier research, e.g., highlighting the role of a strategic management approach in business transformation processes within established firms [142]. The publications in sub-cluster 1.2 thereby focus in particular on IoT-based service-oriented business models, which are intended to help increase the profitability of companies $[98,143]$.

In addition, research also points out moderator variables that have an indirect influence on the main variables input and output. These are in particular security, privacy, legal, and social issues hindering the implementation of IoT (sub-cluster 2.2) as well as the challenge of creating broad acceptance towards it (sub-cluster 3.1). The evaluation (process variable) of the proposed concepts, applications, and architectures, however, receives less or even no attention in research. Only a few moderator variables in the form of evaluation models and test theories are applied or described (sub-clusters 1.3, 2.6, and 3.3) but most researchers leave this to future research. External effects, for example technological progress, economic and political developments and legal situations, which have a direct or indirect influence on the variables of the framework, are also neglected in research. The same applies to potential mediator variables within the framework. Overall, it becomes apparent with the progressive digitalization of all areas of life, IoT is a flourishing concept, which needs further academic attention.

\section{Limitations and Future Research}

The proposed framework not only allows for highlighting the current state of IoT research but also for the identification or potential research gaps. The co-citation analysis has shown that the potential use of IoT architectures or applications is not limited to one domain by the research community but has an impact on almost all business sectors. However, it also shows that the majority of current research is concerned with IoT concepts in specific domains. This poses the risk of limiting the alleged potential of the IoT. Therefore, future research should focus on the conceptualization of generic IoT applications and architectures that can be applied across domains and derive area-specific ones from that.

Furthermore, research regarding the influence of IoT on business model development focuses on how it can be used to create more value for firms. Especially in the production sector, due to a shift from a concentration on the product to a focus on the service [97], strengthening these research efforts in the future could help firms to innovate their business models. It is also essential to further research external factors affecting this process, such as technological progress, legal standards, or growing market competition [92].

While much research attention is focused on the design of IoT concepts, architectures, and applications and their potential impact, the evaluation of these ideas is scarce. Therefore, future research should leave the conceptual stage and focus on practical models for evaluating and actually implementing such ideas.

Another research gap relates to (potential) mediator and moderator variables and their effects. In this context, future studies should, for example, focus on ways to increase acceptance of IoT and how to tackle emerging security and privacy challenges.

Future research should approach the IoT research field from a more generic perspective, instead of a specific domain-based perspective. In addition, a stronger research focus on the evaluation of already developed IoT concepts and applications could help to generate practical use cases and accelerate the process of IoT impact on different areas, such as business model development. Furthermore, more research should be conducted in the future on moderator and mediator effects as well as external influence factors, particularly to answer the question of how to increase the acceptance of IoT among different stakeholders. 
Despite the new insights into the business- and management-specific IoT research landscape, this study is associated with several limitations. First, the data used for the analysis was retrieved from the WoS database alone. As data from other databases was not included, the data set might be incomplete. Future studies should collect more data from other reputable scientific databases such as Scopus or Google Scholar. Second, only the document types 'article', 'early access', and 'review' in the categories of 'business' and 'management' were considered. This might have biased the data set and relevant scientific output may have been excluded. This potential limitation could be addressed by future research, on the one hand, through considering other important knowledge outlets such as books or book chapters, and, on the other hand, through applying a topic rather than a title search. Third, bibliometric analyses may be biased by the so-called Matthew effect, which implies that highly cited documents will continue to be cited only due to their already high number of citations, leading to a potential overvaluation regarding their scientific relevance $[13,144,145]$. Fourth, the clusters that emerged through the co-citation analysis were not precisely delimitable and partly blurred, which is a general problem of bibliometric analyses, as they are citation-based and not content-based. In order to overcome this state and enable a well-founded interpretation of the results, sub-clusters were formed. Consequently, the presented results lose objectivity and tend to be subjective, since the level of knowledge and the opinion of the authors come into play by conducting such a qualitative literature review [146].

Author Contributions: Conceptualization, A.K. and V.T.; methodology, A.K.; software, A.K.; formal analysis, A.K.; investigation, A.K., V.T., and A.B.; resources, A.K.; data curation, A.K.; writingoriginal draft preparation, A.K., V.T., and A.B.; writing-review and editing, V.T. and A.B.; visualization, A.K. All authors have read and agreed to the published version of the manuscript.

Funding: This research received no external funding.

Institutional Review Board Statement: Not applicable.

Informed Consent Statement: Not applicable.

Conflicts of Interest: The authors declare no conflict of interest.

\section{References}

1. Li, S.; Tryfonas, T.; Li, H. The Internet of Things: A security point of view. Internet Res. 2016, 26, 337-359. [CrossRef]

2. Whitmore, A.; Agarwal, A.; Da Xu, L. The Internet of Things-A survey of topics and trends. Inf. Syst. Front. 2015, 17, 261-274. [CrossRef]

3. Galinina, O.; Andreev, S.; Balandin, S.I.; Koucheryavy, Y. (Eds.) Lecture Notes in Computer Science: Internet of Things, Smart Spaces, and Next Generation Networks and Systems. In Proceedings of the 19th International Conference, NEW2AN 2019, and 12th Conference, ruSMART 2019, St. Petersburg, Russia, 26-28 August 2019; Springer: Berlin/Heidelberg, Germany; Volume 11660.

4. Rose, K.; Elridge, S.; Chapin, L. The Internet of Things: An Overview: Understanding the Issues and Challenges of a More Connected World. 2015. Available online: https://www.internetsociety.org/wp-content/uploads/2017/08/ISOC-IoT-Overview20151221-en.pdf (accessed on 17 June 2021).

5. Ashton, K. That 'internet of things' thing. RFID J. 2009, 22, 97-114.

6. Ng, C.K.; Wu, C.H.; Yung, K.L.; Ip, W.H.; Cheung, T. A semantic similarity analysis of Internet of Things. Enterp. Inf. Syst. 2018, 12, 820-855. [CrossRef]

7. Westerlund, M.; Leminen, S.; Rajahonka, M. Designing Business Models for the Internet of Things. Technol. Innov. Manag. Rev. 2014, 4, 5-14. [CrossRef]

8. Weiser, M. The Computer for the 21st Century. Sci. Am. 1991, 265, 94-104. [CrossRef]

9. MacDonald, K.I.; Dressler, V. Using Citation Analysis to Identify Research Fronts: A Case Study with the Internet of Things. Sci. Technol. Libr. 2018, 37, 171-186. [CrossRef]

10. Jesus, E.F.; Chicarino, V.R.L.; De Albuquerque, C.V.N.; Rocha, A.A.D.A. A Survey of How to Use Blockchain to Secure Internet of Things and the Stalker Attack. Secur. Commun. Netw. 2018, 2018, 1-27. [CrossRef]

11. Atzori, L.; Iera, A.; Morabito, G. Understanding the Internet of Things: Definition, potentials, and societal role of a fast evolving paradigm. Ad Hoc Netw. 2017, 56, 122-140. [CrossRef]

12. Vermesan, O.; Friess, P.; Guillemin, P.; Gusmeroli, S.; Sundmaeker, H.; Bassi, A.; Jubert, I.S.; Mazura, M.; Harrison, M.; Eisenhauer, M.; et al. Internet of Things Strategic Research Roadmap. Internet Things-Glob. Technol. Soc. Trends 2011, 1, 9-52. 
13. Tiberius, V.; Schwarzer, H.; Roig-Dobón, S. Radical innovations: Between established knowledge and future research opportunities. J. Innov. Knowl. 2021, 6, 145-153. [CrossRef]

14. Del Sarto, N.; Cesaroni, F.; Di Minin, A.; Piccaluga, A. One size does not fit all. Business models heterogeneity among Internet of Things architecture layers. Technol. Anal. Strateg. Manag. 2021,1-16. [CrossRef]

15. Haaker, T.; Ly PT, M.; Nguyen-Thanh, N.; Nguyen, H.T.H. Business model innovation through the application of the Internet-ofThings: A comparative analysis. J. Bus. Res. 2021, 126, 126-136. [CrossRef]

16. Langley, D.J.; van Doorn, J.; Ng, I.C.; Stieglitz, S.; Lazovik, A.; Boonstra, A. The Internet of Everything: Smart things and their impact on business models. J. Bus. Res. 2021, 122, 853-863. [CrossRef]

17. Nittala, S.S.S.; Bharadwaj, S.S.; Tripathi, S.S.; Seif, H. Service innovation enabled by Internet of Things and cloud computing-A service-dominant logic perspective. Technol. Anal. Strateg. Manag. 2021, 1-14. [CrossRef]

18. Palmaccio, M.; Dicuonzo, G.; Belyaeva, Z.S. The internet of things and corporate business models: A systematic literature review. J. Bus. Res. 2020, 131, 610-618. [CrossRef]

19. Rocha, C.; Fernandes Narcizo, C.; Gianotti, E. Internet of management artifacts: Internet of Things architecture for business model renewal. Int. J. Innov. Technol. Manag. 2019, 16, 1950062. [CrossRef]

20. Saidu, C.; Usman, A.; Ogedebe, P. Internet of Things: Impact on Economy. Br. J. Math. Comput. Sci. 2015, 7, 241-251. [CrossRef]

21. Cisco. Cisco Annual Internet Report (2018-2023). 2020. Available online: https://www.cisco.com/c/en/us/solutions/collateral/ executive-perspectives/annual-internet-report/white-paper-c11-741490.html (accessed on 17 June 2021).

22. Manyika, J.; Chui, M.; Bisson, P.; Woetzel, J.; Dobbs, R.; Bughin, J.; Aharon, D. The Internet of Things: Mapping the Value beyond the Hype. 2015. Available online: https://www.mckinsey.com/ \{\}/media/McKinsey/Industries/Technology\%20Media\%20 and\%20Telecommunications/High\%20Tech/Our\%20Insights/The\%20Internet\%20of\%20Things\%20The\%20value\%20of\%20 digitizing\%20the \%20physical\%20world/Unlocking_the_potential_of_the_Internet_of_Things_Executive_summary.pdf (accessed on 17 June 2021).

23. Kummitha, R.K.R.; Crutzen, N. Smart cities and the citizen-driven internet of things: A qualitative inquiry into an emerging smart city. Technol. Forecast. Soc. Chang. 2019, 140, 44-53. [CrossRef]

24. Rey, A.; Panetti, E.; Maglio, R.; Ferretti, M. Determinants in adopting the Internet of Things in the transport and logistics industry. J. Bus. Res. 2021, 131, 584-590. [CrossRef]

25. Miorandi, D.; Sicari, S.; de Pellegrini, F.; Chlamtac, I. Internet of things: Vision, applications and research challenges. Ad Hoc Netw. 2012, 10, 1497-1516. [CrossRef]

26. ITU-T. Overview of the Internet of Things: Recommendation ITU-T Y.2060. 2012. Available online: http:/ /handle.itu.int/11.100 2/1000/11559 (accessed on 17 June 2021).

27. Fleisch, E. What is the Internet of Things? An Economic Perspective. Econ. Manag. Financ. Mark. 2010, 5, $125-157$.

28. Suddaby, R. Editor's comments: Construct clarity in theories of management and organization. Acad. Manag. Rev. 2010, 35, 346-357. [CrossRef]

29. Rejeb, A.; Simske, S.; Rejeb, K.; Treiblmaier, H.; Zailani, S. Internet of Things research in supply chain management and logistics: A bibliometric analysis. Internet Things 2020, 12, 100318. [CrossRef]

30. Ben-Daya, M.; Hassini, E.; Bahroun, Z. Internet of things and supply chain management: A literature review. Int. J. Prod. Res. 2019, 57, 4719-4742. [CrossRef]

31. Dantu, R.; Dissanayake, I.; Nerur, S. Exploratory Analysis of Internet of Things (IoT) in Healthcare: A Topic Modelling \& Co-citation Approaches. Inf. Syst. Manag. 2021, 38, 62-78. [CrossRef]

32. Bouzembrak, Y.; Klüche, M.; Gavai, A.; Marvin, H.J. Internet of Things in food safety: Literature review and a bibliometric analysis. Trends Food Sci. Technol. 2019, 94, 54-64. [CrossRef]

33. Miskiewicz, R. Internet of Things in Marketing: Bibliometric Analysis. Mark. Manag. Innov. 2020, 3, 371-381. [CrossRef]

34. Dadkhah, M.; Lagzian, M.; Rahimnia, F.; Kimiafar, K. What do Publications say about the Internet of Things Challenges/Barriers to uninformed Authors? A bibliometric Analysis. JLIS 2020, 3, 77-98. [CrossRef]

35. Mishra, D.; Gunasekaran, A.; Childe, S.J.; Papadopoulos, T.; Dubey, R.; Wamba, S. Vision, applications and future challenges of Internet of Things. Ind. Manag. Data Syst. 2016, 116, 1331-1355. [CrossRef]

36. Li, X.; Pak, C.; Bi, K. Analysis of the development trends and innovation characteristics of Internet of Things technology-based on patentometrics and bibliometrics. Technol. Anal. Strateg. Manag. 2020, 32, 104-118. [CrossRef]

37. Erfanmanesh, M.; Abrizah, A. Mapping worldwide research on the Internet of Things during 2011-2016. Electron. Libr. 2018, 36, 979-992. [CrossRef]

38. Madakam, S.; Ramaswamy, R.; Tripathi, S. Internet of Things (IoT): A Literature Review. J. Comput. Commun. 2015, 3, 164-173. [CrossRef]

39. Nascimento, D.A.D.; Neto, A.R.; Filho, E.G.C.; Neto, J.A.C.; Araújo, A.K.R.; Gonçalves, K.L.F.; Leite, F.D.A. A Bibliometric Study about Internet of Things. Int. J. Adv. Eng. Res. Sci. 2019, 6, 213-220. [CrossRef]

40. Sundmaeker, H.; Guillemin, P.; Friess, P.; Woelfflé, S. Vision and Challenges for Realising the Internet of Things; Publications Office of the European Union: Luxembourg, 2010.

41. Singh, D.; Tripathi, G.; Jara, A.J. A Survey of Internet-of-Things: Future Vision, Architecture, Challenges and Services. In 2014 IEEE World Forum on Internet of Things (WF-IoT); IEEE: Piscataway, NJ, USA, 2014; pp. 287-292. [CrossRef]

42. Atzori, L.; Iera, A.; Morabito, G. The Internet of Things: A survey. Comput. Netw. 2010, 54, 2787-2805. [CrossRef] 
43. Patel, K.K.; Patel, S.M. Internet of Things-IOT: Definition, Characteristics, Architecture, Enabling Technologies, Application \& Future Challenges. Int. J. Eng. Sci. Comput. 2016, 6122-6131. [CrossRef]

44. Kosmatos, E.A.; Tselikas, N.D.; Boucouvalas, A.C. Integrating RFIDs and Smart Objects into a Unified Internet of Things Architecture. Adv. Internet Things 2011, 1, 5-12. [CrossRef]

45. Ray, P.P. A survey on Internet of Things architectures. J. King Saud Univ. Comput. Inf. Sci. 2018, 30, 291-319. [CrossRef]

46. Sarkar, C.; Nambi, S.N.A.U.; Prasad, R.V.; Rahim, A. A Scalable Distributed Architecture towards Unifying IoT Applications. In 2014 IEEE World Forum on Internet of Things (WF-IoT); IEEE: Piscataway, NJ, USA, 2014; pp. 508-513. [CrossRef]

47. Tsai, C.-W.; Lai, C.-F.; Vasilakos, A.V. Future Internet of Things: Open issues and challenges. Wirel. Netw. 2014, 20, 2201-2217. [CrossRef]

48. CASAGRAS. Final Report: RFID and the Inclusive Model for the Internet of Things: An EU Framework 7 Project. 2009. Available online: https:/ / docbox.etsi.org/zArchive/TISPAN/Open/IoT/low\%20resolution/www.rfidglobal.eu\%20CASAGRAS\%20IoT\% 20Final\%20Report\%20low\%20resolution.pdf (accessed on 17 June 2021).

49. Li, S.; Da Xu, L.; Zhao, S. The internet of things: A survey. Inf. Syst. Front. 2015, 17, 243-259. [CrossRef]

50. Minerva, R.; Biru, A.; Rotondi, D. Towards a Definition of the Internet of Things (IoT). Telecom Italia S.p.A. 2015. Available online: https://iot.ieee.org/images/files/pdf/IEEE_IoT_Towards_Definition_Internet_of_Things_Revision1_27MAY15.pdf (accessed on 17 June 2021).

51. Guillemin, P.; Friess, P. Internet of Things Strategic Research Roadmap. 2009. Available online: https://sintef.brage.unit.no/ sintef-xmlui/bitstream/handle/11250/2430372/SINTEF\%2BS13363.pdf (accessed on 17 June 2021).

52. Gubbi, J.; Buyya, R.; Marusic, S.; Palaniswami, M. Internet of Things (IoT): A vision, architectural elements, and future directions. Future Gener. Comput. Syst. 2013, 29, 1645-1660. [CrossRef]

53. Höhne, S.; Tiberius, V. Powered by blockchain: Forecasting blockchain use in the electricity market. Int. J. Energy Sect. Manag. 2020, 14, 1221-1238. [CrossRef]

54. Tipantuña, C.; Hesselbach, X. NFV-Enabled Efficient Renewable and Non-Renewable Energy Management: Requirements and Algorithms. Future Internet 2020, 12, 171. [CrossRef]

55. Weyer, J.; Tiberius, V.; Bican, P.M.; Kraus, S. Digitizing grocery retailing: The role of emerging technologies in the value chain. Int J. Innov. Technol. Manag. 2021, 17, 2050058. [CrossRef]

56. Bigini, G.; Freschi, V.; Lattanzi, E. A Review on Blockchain for the Internet of Medical Things: Definitions, Challenges, Applications, and Vision. Future Internet 2020, 12, 208. [CrossRef]

57. Ermolina, A.; Tiberius, V. Voice-Controlled Intelligent Personal Assistants in Health Care: International Delphi Study. J. Med. Internet Res. 2021, 23, e25312. [CrossRef] [PubMed]

58. Gupta, A.; Al-Anbuky, A. IoT-Based Patient Movement Monitoring: The Post-Operative Hip Fracture Rehabilitation Model. Future Internet 2021, 13, 195. [CrossRef]

59. Kelly, J.T.; Campbell, K.L.; Gong, E.; Scuffham, P. The Internet of Things: Impact and Implications for Health Care Delivery. J. Med. Internet Res. 2020, 22, e20135. [CrossRef] [PubMed]

60. Pauget, B.; Dammak, A. The implementation of the Internet of Things: What impact on organizations? Technol. Forecast. Soc. Chang. 2019, 140, 140-146. [CrossRef]

61. Rodrigues, J.J.P.C.; de Rezende Segundo, D.B.; Junqueira, H.A.; Sabino, M.H.; Prince, R.M.; Al-Muhtadi, J.; de Albuquerque, V.H.C. Enabling Technologies for the Internet of Health Things. IEEE Access 2018, 6, 13129-13141. [CrossRef]

62. Tuan, M.N.D.; Thanh, N.N.; Le Tuan, L. Applying a mindfulness-based reliability strategy to the Internet of Things in healthcareA business model in the Vietnamese market. Technol. Forecast. Soc. Chang. 2019, 140, 54-68. [CrossRef]

63. Joyia, G.J.; Liaqat, R.M.; Farooq, A.; Rehman, S. Internet of Medical Things (IOMT): Applications, Benefits and Future Challenges in Healthcare Domain. J. Commun. 2017, 12, 240-247. [CrossRef]

64. Rahman, M.S.; Peeri, N.C.; Shrestha, N.; Zaki, R.; Haque, U.; Hamid, S.H.A. Defending against the Novel Coronavirus (COVID-19) outbreak: How can the Internet of Things (IoT) help to save the world? Health Policy Technol. 2020, 9, 136-138. [CrossRef]

65. Secundo, G.; Shams, S.R.; Nucci, F. Digital technologies and collective intelligence for healthcare ecosystem: Optimizing Internet of Things adoption for pandemic management. J. Bus. Res. 2021, 131, 563-572. [CrossRef]

66. Singh, R.P.; Javaid, M.; Haleem, A.; Suman, R. Internet of things (IoT) applications to fight against COVID-19 pandemic. Diabetes Metab. Syndr. 2020, 14, 521-524. [CrossRef]

67. Swayamsiddha, S.; Mohanty, C. Application of cognitive Internet of Medical Things for COVID-19 pandemic. Diabetes Metab. Syndr. 2020, 14, 911-915. [CrossRef] [PubMed]

68. Yousif, M.; Hewage, C.; Nawaf, L. IoT Technologies during and Beyond COVID-19: A Comprehensive Review. Future Internet 2021, 13, 105. [CrossRef]

69. Arnold, C.; Voigt, K.I. Determinants of industrial internet of things adoption in German manufacturing companies. Int. J. Innov. Technol. Manag. 2019, 16, 1950038. [CrossRef]

70. Jeschke, S.; Brecher, C.; Song, H.; Rawat, D.B. Industrial Internet of Things; Springer International Publishing: Berlin/Heidelberg, Germany, 2017. [CrossRef]

71. Sisinni, E.; Saifullah, A.; Han, S.; Jennehag, U.; Gidlund, M. Industrial Internet of Things: Challenges, Opportunities, and Directions. IEEE Trans. Ind. Inform. 2018, 14, 4724-4734. [CrossRef] 
72. Srinivasan, C.R.; Rajesh, B.; Saikalyan, P.; Premsagar, K.; Yadav, E.S. A review on the different types of internet of things (IoT). J. Adv. Res. Dyn. Control. Syst. 2019, 11, 154-158.

73. Pritchard, A. Statistical Bibliography or Bibliometrics. J. Doc. 1969, 25, 348-349.

74. Zupic, I.; Čater, T. Bibliometric Methods in Management and Organization. Organ. Res. Methods 2015, 18, 429-472. [CrossRef]

75. Alayo, M.; Iturralde, T.; Maseda, A.; Aparicio, G. Mapping family firm internationalization research: Bibliometric and literature review. Rev. Manag. Sci. 2021, 15, 1517-1560. [CrossRef]

76. Del Pilar Casado-Belmonte, M.; de las Mercedes Capobianco-Uriarte, M.; Martínez-Alonso, R.; Martínez-Romero, M.J. Delineating the Path of Family Firm Innovation: Mapping the Scientific Structure. Rev. Manag. Sci. 2021. [CrossRef]

77. Díez-Martín, F.; Blanco-González, A.; Prado-Román, C. The intellectual structure of organizational legitimacy research: A co-citation analysis in business journals. Rev. Manag. Sci. 2021, 15, 1007-1043. [CrossRef]

78. Ellegaard, O.; Wallin, J.A. The bibliometric analysis of scholarly production: How great is the impact? Scientometrics 2015, 105, 1809-1831. [CrossRef] [PubMed]

79. Filser, M.; Tiberius, V.; Kraus, S.; Zeitlhofer, T.; Kailer, N.; Müller, A. Opportunity recognition: Conversational foundations and pathways ahead. Entrep. Res. J. 2020, 20200124. [CrossRef]

80. Glinyanova, M.; Bouncken, R.B.; Tiberius, V.; Cuenca Ballester, A.C. Five decades of corporate entrepreneurship research: Measuring and mapping the field. Int. Entrep. Manag. J. 2021. [CrossRef]

81. Hillmann, J. Disciplines of organizational resilience: Contributions, critiques, and future research avenues. Rev. Manag. Sci. 2021. [CrossRef]

82. Kraus, S.; Li, H.; Kang, Q.; Westhead, P.; Tiberius, V. The sharing economy: A bibliometric analysis of the state-of-the-art. Int. J. Entrep. Behav. Res. 2020, 26, 1769-1786. [CrossRef]

83. Tiberius, V.; Siglow, C.; Sendra-García, J. Scenarios in business and management: The current stock and research opportunities. J. Bus. Res. 2020, 121, 235-242. [CrossRef]

84. Vogel, R.; Güttel, W.H. The Dynamic Capability View in Strategic Management: A Bibliometric Review. Int. J. Manag. Rev. 2013, 15, 426-446. [CrossRef]

85. Zhao, D.; Strotmann, A. The knowledge base and research front of information science 2006-2010: An author cocitation and bibliographic coupling analysis. J. Assoc. Inf. Sci. Technol. 2014, 65, 995-1006. [CrossRef]

86. Leydesdorff, L.; Vaughan, L. Co-occurrence matrices and their applications in information science: Extending ACA to the Web environment. J. Am. Soc. Inf. Sci. Technol. 2006, 57, 1616-1628. [CrossRef]

87. Small, H. Co-citation in the scientific literature: A new measure of the relationship between two documents. J. Am. Soc. Inf. Sci. 1973, 24, 265-269. [CrossRef]

88. Wang, N.; Liang, H.; Jia, Y.; Ge, S.; Xue, Y.; Wang, Z. Cloud computing research in the IS discipline: A citation/co-citation analysis. Decis. Support. Syst. 2016, 86, 35-47. [CrossRef]

89. Hota, P.K.; Subramanian, B.; Narayanamurthy, G. Mapping the Intellectual Structure of Social Entrepreneurship Research: A Citation/Co-citation Analysis. J. Bus. Ethics 2020, 166, 89-114. [CrossRef]

90. Van Eck, N.J.; Waltman, L. Software survey: Vosviewer, a computer program for bibliometric mapping. Scientometrics 2010, 84, 523-538. [CrossRef]

91. Chan, H.C.Y. Internet of Things Business Models. J. Serv. Sci. Manag. 2015, 8, 552-568. [CrossRef]

92. Porter, M.E.; Heppelmann, J.E. How Smart, Connected Products Are Transforming Competition. Harv. Bus. Rev. 2014, 92, 64-88.

93. Johnson, M.W.; Christensen Clayton, M.; Kagermann, H. Reinventing Your Business Model. Harv. Bus. Rev. 2008, 86, 51-59.

94. Zott, C.; Amit, R. Business Model Design: An Activity System Perspective. Long Range Plan. 2010, 43, 216-226. [CrossRef]

95. Zott, C.; Amit, R.; Massa, L. The Business Model: Recent Developments and Future Research. J. Manag. 2011, 37, 1019-1042. [CrossRef]

96. Dijkman, R.M.; Sprenkels, B.; Peeters, T.; Janssen, A. Business models for the Internet of Things. Int. J. Inf. Manag. 2015, 35, 672-678. [CrossRef]

97. Frank, A.G.; Mendes, G.H.; Ayala, N.F.; Ghezzi, A. Servitization and Industry 4.0 convergence in the digital transformation of product firms: A business model innovation perspective. Technol. Forecast. Soc. Chang. 2019, 141, 341-351. [CrossRef]

98. Rymaszewska, A.; Helo, P.; Gunasekaran, A. IoT powered servitization of manufacturing-An exploratory case study. Int. J. Prod. Econ. 2017, 192, 92-105. [CrossRef]

99. Benbasat, I.; Goldstein, D.K.; Mead, M. The Case Research Strategy in Studies of Information Systems. MIS Q. 1987, 11, 369. [CrossRef]

100. Eisenhardt, K.M. Building Theories from Case Study Research. Acad. Manag. Rev. 1989, 14, 532-550. [CrossRef]

101. Eisenhardt, K.M.; Graebner, M.E. Theory Building from Cases: Opportunities And Challenges. Acad. Manag. J. $2007,50,25-32$. [CrossRef]

102. Yin, R.K. Case Study Research: Design and Methods, 4th ed.; Applied Social Research Methods Series; Sage Publications: Thousand Oaks, CA, USA, 2009; Volume 5.

103. Lee, I.; Lee, K. The Internet of Things (IoT): Applications, investments, and challenges for enterprises. Bus. Horiz. 2015, 58, 431-440. [CrossRef]

104. Kim, S.; Kim, S. A multi-criteria approach toward discovering killer IoT application in Korea. Technol. Forecast. Soc. Chang. 2016, 102, 143-155. [CrossRef] 
105. Weber, R.H. Internet of Things-New security and privacy challenges. Comput. Law Secur. Rev. 2010, 26, 23-30. [CrossRef]

106. Sicari, S.; Rizzardi, A.; Grieco, L.A.; Coen-Porisini, A. Security, privacy and trust in Internet of Things: The road ahead. Comput. Netw. 2015, 76, 146-164. [CrossRef]

107. Guo, B.; Zhang, D.; Wang, Z.; Yu, Z.; Zhou, X. Opportunistic IoT: Exploring the harmonious interaction between human and the internet of things. J. Netw. Comput. Appl. 2013, 36, 1531-1539. [CrossRef]

108. Dutton, W.H. Putting things to work: Social and policy challenges for the Internet of things. Info 2014, 16, 1-21. [CrossRef]

109. Yan, Z.; Zhang, P.; Vasilakos, A.V. A survey on trust management for Internet of Things. J. Netw. Comput. Appl. 2014, 42, 120-134. [CrossRef]

110. Ng, I.; Scharf, K.; Pogrebna, G.; Maull, R. Contextual variety, Internet-of-Things and the choice of tailoring over platform: Mass customisation strategy in supply chain management. Int. J. Prod. Econ. 2015, 159, 76-87. [CrossRef]

111. Parry, G.C.; Brax, S.A.; Maull, R.S.; Ng, I.C.L. Operationalising IoT for reverse supply: The development of use-visibility measures. Supply Chain Manag. Int. J. 2016, 21, 228-244. [CrossRef]

112. Khan, R.; Khan, S.U.; Zaheer, R.; Khan, S. Future Internet: The Internet of Things Architecture, Possible Applications and Key Challenges. In Proceedings of the 2012 10th International Conference on Frontiers of Information Technology, Islamabad, Pakistan, 17-19 December 2012; IEEE: Piscataway, NJ, USA; pp. 257-260. [CrossRef]

113. Zanella, A.; Bui, N.; Castellani, A.; Vangelista, L.; Zorzi, M. Internet of Things for Smart Cities. IEEE Internet Things J. 2014, 1, 22-32. [CrossRef]

114. Webster, J.; Watson, R. Analyzing the Past to Prepare for the Future: Writing a Literature Review. MIS Q. 2002, 26, xiii-xxiii.

115. Gao, L.; Bai, X. A unified perspective on the factors influencing consumer acceptance of internet of things technology. Asia Pac. J. Mark. Logist. 2014, 26, 211-231. [CrossRef]

116. Venkatesh, V.; Morris, M.G.; Davis, G.B.; Davis, F.D. User Acceptance of Information Technology: Toward a Unified View. MIS Q. 2003, 27, 425. [CrossRef]

117. Venkatesh, V.; Davis, F.D. A Theoretical Extension of the Technology Acceptance Model: Four Longitudinal Field Studies. Manag. Sci. 2000, 46, 186-204. [CrossRef]

118. Mital, M.; Chang, V.; Choudhary, P.; Papa, A.; Pani, A.K. Adoption of Internet of Things in India: A test of competing models using a structured equation modeling approach. Technol. Forecast. Soc. Chang. 2018, 136, 339-346. [CrossRef]

119. Vargo, S.L.; Lusch, R.F. Evolving to a New Dominant Logic for Marketing. J. Mark. 2004, 68, 1-17. [CrossRef]

120. Vargo, S.L.; Lusch, R.F. Service-dominant logic: Continuing the evolution. J. Acad. Mark. Sci. 2008, 36, 1-10. [CrossRef]

121. Barney, J. Firm Resources and Sustained Competitive Advantage. J. Manag. 1991, 17, 99-120. [CrossRef]

122. Teece, D.J.; Pisano, G.; Shuen, A. Dynamic capabilities and strategic management. Strateg. Manag. J. 1997, 18, 509-533. [CrossRef]

123. Anderson, J.C.; Gerbing, D.W. Structural equation modeling in practice: A review and recommended two-step approach. Psychol. Bull. 1988, 103, 411-423. [CrossRef]

124. Cohen, W.M.; Levinthal, D.A. Absorptive Capacity: A New Perspective on Learning and Innovation. Adm. Sci. Q. 1990, $35,128$. [CrossRef]

125. Fornell, C.; Larcker, D.F. Evaluating Structural Equation Models with Unobservable Variables and Measurement Error. J. Mark. Res. 1981, 18, 39. [CrossRef]

126. Hair, J.F. Multivariate Data Analysis: With Readings, 4th ed.; Prentice Hall: Hoboken, NJ, USA, 1995.

127. Podsakoff, P.M.; MacKenzie, S.B.; Lee, J.-Y.; Podsakoff, N.P. Common method biases in behavioral research: A critical review of the literature and recommended remedies. J. Appl. Psychol. 2003, 88, 879-903. [CrossRef]

128. Rogers, E.M. Diffusion of Innovations, 5th ed.; Free Press: New York, NY, USA; London, UK; Toronto, ON, Canada; Sydney, Australia, 2003.

129. Scuotto, V.; Ferraris, A.; Bresciani, S. Internet of Things: Applications and challenges in smart cities. A case study of IBM smart city projects. Bus. Process Manag. J. 2016, 22. [CrossRef]

130. Yang, L.; Yang, S.H.; Plotnick, L. How the internet of things technology enhances emergency response operations. Technol. Forecast. Soc. Chang. 2013, 80, 1854-1867. [CrossRef]

131. Ma, H.-D. Internet of Things: Objectives and Scientific Challenges. J. Comput. Sci. Technol. 2011, 26, 919-924. [CrossRef]

132. Medaglia, C.M.; Serbanati, A. An Overview of Privacy and Security Issues in the Internet of Things. In The Internet of Things; Giusto, D., Iera, A., Morabito, G., Atzori, L., Eds.; Springer: New York, NY, USA, 2010; pp. 389-395. [CrossRef]

133. Chen, M.; Mao, S.; Liu, Y. Big Data: A Survey. Mob. Netw. Appl. 2014, 19, 171-209. [CrossRef]

134. Chen, H.; Chiang, R.H.; Storey, V.C. Business Intelligence and Analytics: From Big Data to Big Impact. MIS Q. $2012,36,1165$. [CrossRef]

135. Domingo, M.C. An overview of the Internet of Things for people with disabilities. J. Netw. Comput. Appl. 2012, 35, 584-596. [CrossRef]

136. Kortuem, G.; Kawsar, F.; Sundramoorthy, V.; Fitton, D. Smart objects as building blocks for the Internet of things. IEEE Internet Comput. 2010, 14, 44-51. [CrossRef]

137. Borgia, E. The Internet of Things vision: Key features, applications and open issues. Comput. Commun. 2014, 54, 1-31. [CrossRef]

138. Bradley, J.; Barbier, J.; Handler, D. Embracing the Internet of Everything To Capture Your Share of \$14.4 Trillion: More Relevant, Valuable Connections Will Improve Innovation, Productivity, Efficiency \& Customer Experience. Cisco. 2013. Available online: https:/ / www.cisco.com/c/dam/en_us/about/ac79/docs/innov /IoE_Economy.pdf (accessed on 17 June 2021). 
139. Xu, B.; Da Xu, L.; Cai, H.; Xie, C.; Hu, J.; Bu, F. Ubiquitous Data Accessing Method in IoT-Based Information System for Emergency Medical Services. IEEE Trans. Ind. Inform. 2014, 10, 1578-1586. [CrossRef]

140. Atzori, L.; Iera, A.; Morabito, G.; Nitti, M. The Social Internet of Things (SIoT)—When social networks meet the Internet of Things: Concept, architecture and network characterization. Comput. Netw. 2012, 56, 3594-3608. [CrossRef]

141. Tao, F.; Cheng, Y.; Da Xu, L.; Zhang, L.; Li, B.H. CCIoT-CMfg: Cloud Computing and Internet of Things-Based Cloud Manufacturing Service System. IEEE Trans. Ind. Inform. 2014, 10, 1435-1442. [CrossRef]

142. Agarwal, N.; Brem, A. Strategic business transformation through technology convergence: Implications from General Electric's industrial internet initiative. Int. J. Technol. Manag. 2015, 67, 196-214. [CrossRef]

143. Lightfoot, H.; Baines, T.; Smart, P. The servitization of manufacturing. Int. J. Oper. Prod. Manag. 2013, 33, 1408-1434. [CrossRef]

144. Larivière, V.; Gingras, Y. The impact factor's Matthew Effect: A natural experiment in bibliometrics. J. Am. Soc. Inf. Sci. Technol. 2010, 61, 424-427. [CrossRef]

145. Perc, M. The Matthew effect in empirical data. J. R. Soc. Interface 2014, 11, 20140378. [CrossRef]

146. Schröder, K.; Tiberius, V.; Bouncken, R.B.; Kraus, S. Strategic entrepreneurship: Mapping a research field. Int. J. Entrep. Behav. Res. 2020, 27, 753-776. [CrossRef] 